\title{
SPILLOVER EFFECT BETWEEN ENERGY PRICE SHOCKS ON STOCK MARKET: EVIDENCE FROM SECTORAL INDICES IN TURKEY
}

\author{
DOI: 10.17261/Pressacademia.2021.1523 \\ PAP- V.14-2021(49)-p.167-168
}

\section{Elif Erer}

Independent Researcher, Izmir, Turkey.

elif_erer@hotmail.com, ORCID: 0000-0002-2238-4602

\section{To cite this document}

Erer, E., (2021). Spillover effect between energy price shocks on stock market: evidence from sectoral indices in Turkey. PressAcademia Procedia (PAP), 14, 167-168.

Permanent link to this document: http://doi.org/10.17261/Pressacademia.2021.1523

Copyright: Published by PressAcademia and limited licensed re-use rights only.

\section{ABSTRACT}

Purpose- The purpose of this study is to investigate the spillover effect of energy price shocks on aggregate stock market and sub-sectoral indices including industrial, food and beverage, technology and metarial during the period of Covid-19 pandemic. Energy prices, which play an important role on macroeconomic and financial factors, and their shocks affect several industries differently. Recently, European energy crisis due to decline in gas storage levels indicate once again that upward movements oil and gas prices lead to serious adverse conditions in various sectors by raising energy costs. In the world, the energy insfrastructure has an interwined struture. Thus, distruptions which may be seen in any chain on the industrial side will negatively influence many sectors from food to technology. Also, energy sector is expected to face critical changes in the near future because of climate changes. This situation may challenges in price formation of energy prices. So, examining of the impact of price movements in energy sector on various sectors become more of one issue of the main research areas in risk management.

Methodology- The study employs DCC-GARCH model, which is one of the multivariate GARCH models, to reveal the spillover effect from energy price shocks to sectoral indices. DCC-GARCH model proposed by Tse and Tsui (2002) estimates conditional correlation parameters to indicate spillover effects between variables. This model allows to relatively easy parameters estimation and to modeling of interdependence in volatility. Thanks to this model, it is analysed between variables by estimating time-varying conditional correlation. After determining of spillover effect between energy price shocks and stock market indices, causality in variance proposed by Hafner and Herwartz (2006) is applied to specify the way of spillover effects. This test have the advantages that it is not necessary to model the internal dynamics simultaneously, it allows the causality in variance to examined by considering multiple lag lengths, and the model selection does not affect the success of the test.

Findings- The analysis reveals that the there is highly volatility spillover effect between energy prices and industrial, food and beverage and metarial sector indices. However, it is seen that technological sector index underreacts to energy prices. With respect to the results of Hafner and Herwartz causality in variance, energy price shocks caused volatility shifting in ndustrial, food and beverage and metarial sector indices. Increases in energy prices lead to volatility spillover effect from energy sector to industrial, food and beverage and metarial secotrs due to energy crisis by raising production cost. The results are of importance in terms of risk management, heding strategies and asset pricing. Conclusion- Based upon the analysis findings it may be concluded that policy makers should implement the policies to moderate the adverse impact of increasing energy prices on the economy. So, renewable and environment friendly energy policies become more of an issue. At this point, firms should produce via clean and renewable resources and update their strategies dynamically.

Keywords: Energy crisis, financial markets, environmental economics, multivariate GARCH, causality in variance JEL Codes: Q40, Q54, C58

\section{REFERENCES}

Baumeister, C., \& Kilian, L. (2016). Forty years of oil price fluctuations: Why the price of oil may still surprise us. Journal of Economic Perspectives, 30(1), 139-60.

Cong, R. G., \& Shen, S. (2013). Relationships among energy price shocks, stock market, and the macroeconomy: evidence from China. The Scientific World Journal.

Farzanegan, M. R., \& Markwardt, G. (2009). The effects of oil price shocks on the Iranian economy. Energy economics, 31(1), 134-151. 
Hafner, C. M., \& Herwartz, H. (2006). A Lagrange multiplier test for causality in variance. Economics letters, 93(1), 137-141.

Ji, Q., \& Fan, Y. (2012). How does oil price volatility affect non-energy commodity markets?. Applied Energy, 89(1), 273-280.

Kapusuzoglu, A., \& Ulusoy, M. K. (2015). The interactions between agricultural commodity and oil prices: an empirical analysis. Agricultural Economics, 61(9), 410-421.

Kirikkaleli, D., \& Güngör, H. (2021). Co-movement of commodity price indexes and energy price index: a wavelet coherence approach. Financial Innovation, 7(1), 1-18.

Lucotte, Y. (2016). Co-movements between crude oil and food prices: A post-commodity boom perspective. Economics Letters, 147, 142147.

Tse, Y. K., \& Tsui, A. K. C. (2002). A multivariate generalized autoregressive conditional heteroscedasticity model with time-varying correlations. Journal of Business \& Economic Statistics, 20(3), 351-362. 